\title{
Understanding Ethnic Minorities in Eastern Europe
}

\author{
Sherrill Stroschein
}

s.stroschein@ucl.ac.uk

April, 2016 (revised from 2015)

\section{Introduction}

This chapter presents a summary examination of ethnic minorities in Eastern Europe. The chapter first provides a historical overview of the development of the concept of ethnic minorities, which will show how the emergence and change of state borders in the region have produced ethnically diverse states out of empires. Politically-mobilised ethnic groups first truly emerged during the 1800 s in the region. Ethnicity was then subsumed within the socialist political structures but emerged as a strong political force in post-1989 democratisation processes. Following this historic and demographic overview, the chapter then sketches some of the key ideas on how ethnic groups matter in society and politics. The discussion outlines general dynamics of ethnic relations, mobilisation, and group goals, and then turns to ethnic minority parties, elections, and decentralisation. The piece concludes with a consideration of the promise and limitations of these general ideas in the complex ethnic context of Eastern Europe.

\section{Ethnic Minorities in Eastern Europe}

The geographical area known as Eastern Europe has been a place of population movements, wars, and border changes spanning over a thousand years. The way in which the mixing of these diverse populations has been understood has changed across time, in relation to different political events. Up until 1050, many parts of the region were included in empires, such as the Roman, Byzantine, and Bulgarian empires (Magocsi 1993: 6-11, Hupchick and Cox 2001a, 2001b). For the next few hundred years, the region featured medieval kingdoms such as those of Poland, Hungary, Croatia, Bulgaria, Serbia, and Kievan Rus', as well as the Holy Roman Empire (Magocsi 1993: 13-15, Hupchick and Cox 2001a, 2001b). In the 1400s the Ottoman Empire began to advance into the region, and by the late 1500 s the Ottomans controlled lands as far north and west as Hungary and Croatia (Magocsi 1993: 47, Szakály in Sugar et al 1990, p. 87, Lendvai 2003, p. 98). The Habsburgs regained control of Hungary and Croatia by 1683 , but the Balkan lands including Bosnia, south Serbia, south Romania, and Bulgaria remained under Ottoman control until the late 1800 s (Hupchick and Cox 2001b, Map 26). A long period of declining Ottoman powers in the region was then followed by the First World War (Magocsi 1993: 63-65, 68, 85; Kann and David 1984: 6-13, Carnegie Endowment 1993).

The peace agreements following the war carved the region into states that are familiar to us today, although the region's border was moved westward with the Soviet Union's acquisition of some eastern territories after the Second World War, changing the shapes of the states to a map that we can recognise today (Rothschild 1989: 2; Rothschild 1992: 2, Hupchick and Cox 2001a). However, after 1991 modifications were also made to the borders of the post-war map, with the collapse of Soviet, Czechslovak, and Yugoslav federal states into smaller units.

This extremely complex history has aligned with shifts in what it means to be a minority, including an ethnic minority. For several hundred years, minority status was often tied to a religious identity. To be a Serb in the Ottoman Empire meant to be an Orthodox Christian rather than a Muslim, though this difference also came with economic implications (Jelavich 1983: 91-92, Banac 
1984, pp. 59-69). Identity was retained through language to some degree. However, as the business of empires was conducted in a common language, languages that were not used for official purposes, such as Czech, tended to be more common in domestic spheres during the age of empires (Glassheim 2005).

An understanding of ethnicity and nationalism as motivations in politics that is similar to today's understanding began to emerge in the 1800s (Banac 1984, p. 79). Some of uprisings of Serbs against the Ottoman Empire in the early 1800s featured an aspect of ethnic identity, though Serbian grievances also reflected their economic circumstances (Jelavich 1983: 196-203). Jelavich (1983) links this nationalist development to the ideas of the German philosopher Johann Gottfried Herder, who outlined the Volk, or people, as being a crucial unit of society that took priority over individual interests. These ideas also contained an explicit link to language and culture (Jelavich 1983: 172-74).

In 1848, there were a series of popular uprisings against the Austro-Hungarian Empire (the Habsburgs). The notion of a national identity linked to language and culture was clearly reflected in these mobilisations. There are several lines of thought about the emergence of nationalism as a political identity that implied a connection between a national group and governance of that group. Some historians, such as Smith (1986), noted that while this particular manifestation of identity might be modern, elements of nations such as their ethnic roots and myths were in fact ancient. The view that nations have deeply historical roots is also often reflected in interviews with self-identified nationalists in the region.

A contrasting view focuses on nations as being constructed by modern forces, beginning in the 1800s in particular. Anderson (1991) posited that national identities became salient along with the advent of newspapers and print capitalism. Newspapers presented far away events as connected to individuals because of their shared language, culture, and identity, and they thus created "imagined communities" of nations. As he describes, "[T]he members of even the smallest nation will never know most of their fellow-members, meet them, or even hear of them, yet in the minds of each lives the image of their communion" (Anderson 1991: 6). Gellner saw nationalism, or the political notion that nations and states should align, as a kind of secular religion that was instilled by state governments through an education system, an inherently modern trait of an industrial society (1983). A somewhat similar perspective is outlined by Hobsbawm (1992), who emphasises how the idea of nationalism is used by governing elites to ensure popular mobilisation.

Is nationalism connected more to ethnicity, language, religion, culture, or other traits? In Connor's (1994) useful breakdown, nationalism is often confused with a number of these traits. Like Gellner, Connor instead focuses on the way in which it can be used for political ends. The claim that nations and states go together is one that both authors question. The term nation-state is an especially problematic example of a lack of careful language with regard to these concepts. The notion that nations and states should be "congruent" (Gellner 1983:1) is a political project, one that should be critically examined by observers.

For conceptual clarity, it is useful to consider traits such as ethnicity, language, religion, and culture as potential items on the menu of nations. One trait is sufficient to demarcate a nation, but a combination of traits may also be present. In addition, to avoid muddling concepts, it can be useful to think of nations in terms of Anderson's imagined communities, with nationalism as a political manifestation of the national identity. In terms of sentiment toward a state, patriotism is a more appropriate word. Ethnic minorities, then, exhibit specific traits of descent (Chandra 2006) that differ from that of the state's titular group, or the ethnicity reflected in the state's name (Laitin 1999). For example, ethnic Slovaks are the titular group in Slovakia, while ethnic Hungarians are an ethnic minority there. The degree to which these ethnic traits matter for politics will vary according to the political context. More is said about these latent versus mobilised differences below.

During the period of socialism in Eastern Europe, political mobilisations outside of the Socialist Party line were discouraged. Ethnic minorities were allowed to participate in activities that 
took place within the government regime, but were prohibited from any activities that regimes perceived as challenging their rule. Minority cultural organisations such as dance groups were often encouraged and even funded by the state. In addition, in most states ethnic minorities were allowed to attend schools in their own language, even at university level in some cases. There were some exceptions to this rule. For example, the practice of ethnicity was more problematic in the context of the Former Yugoslavia, where Josip Broz Tito's regime emphasised a common "Yugoslav" identity in the wake of a brutal civil war between groups during the Second World War.

Separate religious identities were more complicated in terms of their relationship to the state. Socialism tended to be secular, but religious officials exhibited varied types of relationships with the state in different contexts. Some religious officials were jailed for their beliefs or actions, as was the case for some Hungarian leaders in Romania - a treatment sometimes linked to their status as ethnic minorities. Ethnic minority mobilization in religious terms was antithetical to the Socialist regimes, and thus was treated with suspicion by these governments. Ethnic minorities might have their own newspapers and separate Socialist organizations - as was the case for Hungarian minorities throughout the region -- but all of these institutions had to stay within the official party line to continue their operations (Stroschein 2012: 83-84). With the collapse of the Socialist regimes in 1989, ethnic minorities quickly became politically mobilised, often forming their own parties.

\section{Ethnic Minorities, Regime Change, and Democracy}

The political upheavals in 1989 included mobilisation by ethnic Hungarians in Timișoara, Romania, when the government attempted to arrest an ethnic Hungarian protestant minister (Gati 1990: 183-84; Stokes 1993: 163). Romania's December 1989 transition involved significant violence between protesters and government forces. Violence also erupted in March 1990 between ethnic Hungarians and Romanians in the mixed city of Târgu Mureș, originating in a conflict over the language of instruction in local schools. In spite of tensions and disagreements, however, there was no further inter-group violence on this scale in Romania (Stroschein 2012: 97-102).

By the spring and summer of 1991, there were skirmishes and then violence between Serbs and Croats in relation to the Croat and Slovene declarations of independence from Yugoslavia (Glenny 1993). When Bosnia and Herzegovina declared independence in 1992, it became the site of a brutal civil war between mixed ethnic / religious groups. It was in the course of this conflict that the term "ethnic cleansing" was frequently used - the notion that group mixing should be reversed through violence, with the aim of creating ethnically homogenous populations. This conflict was only brought to an end with the internationally-brokered Dayton Peace Agreement in November 1995. Ethnic mixing became "unmixed" in both Croatia and Bosnia and Herzegovina. Bosnia had been particularly demographically mixed before these wars, and as a result of the violence a large portion of the Bosnian population was displaced (Glenny 1992, Woodward 1995).

The Yugoslav conflicts are often described as ethnic, between ethnic Serbs, Croats, and Bosnians (see also Bieber in this volume). However, they might be better understood as an effort to establish political control over territories by elites invoking a national identity. Yugoslavia first started to unravel with Slovenia and Croatia declaring independence in 1991. These declarations were followed by a Yugoslav National Army (JNA) response that produced limited violence in homogenous Slovenia. However, the JNA response and the new Croatia's counter-response produced more protracted violence in Croatia, with initial Yugoslav attempts to stop its secession and then the Croatian government's efforts to pressure its Serbian population to leave (Glenny 1993). When heavily-mixed Bosnia and Herzegovina declared independence in 1992, a three-way civil war between Serbs, Croats, and Bosniaks (or Muslims), embroiled the country until 1995 (Woodward 1995). Religion was often invoked during the wars, and victims were sometimes identified by religious markers, including their ability to recite certain prayers. Serbs tend to be Christian Orthodox, Croats tend to be Catholic, and Bosnians have become known as Muslim - 
although there are certainly secular individuals in each group. The complexity of the Bosnian conflict produced a small academic industry from attempts to explain these and related events.

Yugoslavia was one of three states to fragment into component parts as a result of ethnic mobilisation. The federation of Czechoslovakia also dissolved into its Czech and Slovak component parts in 1993, but did so in a non-violent fashion. Eastern Europe today is also generally considered to contain the Baltic states of Estonia, Latvia, and Lithuania, which declared independence from the Soviet Union in 1991 and have established themselves as sovereign states. Latvia and Estonia in particular contain large Russian populations.

The table below gives a breakdown of the ethnic composition of the region's countries in the wake of these events.

Table 1: Ethnic minority groups in East European countries (Sourced from: Sebők 1998, Rothschild 1992, Senn 1997, Muiznieks 1997, Raun 1997, cross-checked with current census data) ${ }^{1}$

\begin{tabular}{|l|l|l|}
\hline Country & Titular ethnic group & $\begin{array}{l}\text { Significant current ethnic } \\
\text { minorities, 3 \% or more of one } \\
\text { group* }\end{array}$ \\
\hline & & \\
\hline Estonia & Estonians & Russians \\
\hline Latvia & Latvians & Russians \\
\hline Lithuania & Lithuanians & Poles, Russians \\
\hline Poland & Poles & (only small groups recorded) \\
\hline Czech Republic & Czechs & Moravians \\
\hline Slovakia & Slovaks & Hungarians \\
\hline Hungary & Hungarians & Roma \\
\hline Slovenia & Slovenes & (only small groups recorded) \\
\hline Croatia & Croats & Serbs \\
\hline Bosnia and Herzegovina & Bosnians & Serbs, Croats \\
\hline Serbia & Serbs & Hungarians \\
\hline Macedonia & 3acedonians & Albanians, Turks \\
\hline Kosovo & Maced & Serbs \\
\hline Albania & Kosovar Albanians & (only small groups recorded) \\
\hline Romania & Albanians & Hungarians, Roma \\
\hline Moldova & Romanians & Ukrainians, Russians, Gagauz \\
\hline Bulgaria & Moldovans & Turks, Roma \\
\hline & Bulgarians & \\
\hline & & \\
\hline
\end{tabular}

*Roma are vastly under-recorded in this kind of data, and thus in the table. But there is a visible Roma presence in most countries of the region.

\footnotetext{
${ }^{1}$ Wikipedia data on these censuses is useful, but should be cross-checked with other sources.

${ }^{2}$ Bosniaks are the titular group here in name, but Serbs and Croats are also treated as constituent nations that are part of the government structure established by Dayton Peace Agreement (1995).

${ }^{3}$ Due to a name dispute with Greece, the formal name of this country is the Former Yugoslav Republic of Macedonia (FYR Macedonia or FYROM).

${ }^{4}$ Due to a boycott of the latest census by many Serbs, this percentage is not clear.

${ }^{5}$ Due to some changes, the percentage of Romanians may increase in the 2014 census, to be released between late 2016 and 2017. I am grateful to Eleanor Knott for this note, via correspondence.
} 
The sections that follow outline some key understandings on ethnic minority politics that relate to the East European mobilisations. The chapter then presents an overview of ethnic politics considerations in democracies, including parties, elections, and constitutional options.

\section{A. Ethnic Mobilisation}

During the 1990s, a common phrase used in relation to ethnicity and Eastern Europe was that the collapse of the socialist regimes had "taken the lid off of the cauldron" of ethnic conflicts that were simmering underneath Socialist rule. Robert Kaplan's book Balkan Ghosts became a popular book due to its rich description of some of the cultural traditions that the author had found during his travels in the region. Likely intended to simply be a travel book, it was also used by some policymakers in an attempt to avoid intervention in Bosnia and Herzegovina because the region was a morass of "ancient hatreds". During the Yugoslav wars of the early 1990s, many scholars approached this view as a foil, and instead tried to draw attention to the nuanced motivations for ethnic political mobilisations.

One set of ideas that appeared fruitful to theorists trying to explain the ethnic mobilisation and conflict of the 1990s came from the 1950s. One longstanding line of thought on ethnic relations regards the question of whether increased contact between individuals of different groups produces more tolerance or more conflict. The contact hypothesis reflects a view indicated in Allport (1954), which posits that increased contact between individuals of different groups provides increased information that should promote tolerance. An opposing view, the conflict hypothesis, posits that the more one learns about the other, the less one may like the other. This notion was also reflected in survey work by Massey, Hodson, and Sekulić (1999: 670) in Yugoslavia before the onset of war, which indicated the highest levels of ethnic intolerance to lie in ethnic enclaves, where there were concentrations of "similarly identified people". The contact hypothesis ideas are oriented to a focus of ties and networks between individuals.

A contrasting view is a focus on individual cost-benefit calculations, as emphasised by rational-choice and strategic models. Fearon (1994) explained the unfolding of the Serb-Croat skirmishes in 1991 with this approach, informed by international relations theories on security. He outlined that a security dilemma existed between the groups in which it became rational to attack first. His work on the inability of groups to make credible commitments to each other (the "commitment problem") became part of the standard language applied to explain the conflict. A later development of rationalist theory by Fearon and Laitin (1996) outlined that leaders of groups might punish individuals who engage in conflicts, and thus that a strong role for leaders is crucial to maintain inter-group peace - and not contact between individuals of those groups, which is to be discouraged in their model.

Another approach to explaining ethnic conflict in the region is the elite manipulation hypothesis, put forward by Snyder (2000). In this view, elites eager to gain support in new democracies will take an extreme ethnic or nationalist stance in order to win votes. This theory became very popular in the policy community in their approach to the region, as it presented a set of achievable tasks. If elites and a nationalist rhetoric were the source of the problem, various projects could counter these elites and this rhetoric. In addition to the war in Yugoslavia, ethnic clashes between Romanians and Hungarians began to be explained as due to the machinations of elites. Several non-governmental organisation (NGO) projects funded by Western donors attempted to address these issues. Some NGOs arranged meetings between elites of different groups, or between ordinary people of different groups in an effort to get them to talk with each other. In addition, a number of efforts to write "true" and "neutral" histories of the region emerged as well, but with 
little resonance within populations. It is noteworthy that these theories did not fully consider why populations might respond to these machinations of elites.

Another line of focus in the literature examines transnational aspects of ethnic minority group mobilisation. Brubaker (1996) proposed the term "triadic nexus" to illustrate the political dynamics that take place between ethnic minorities and their state governments - as well as their "external national homelands," or the states with which they do share a title. As one example, the dynamics of politics between the Hungarian ethnic minority in Romania and the Romanian government also involve the external Hungarian "homeland" state. Later work began to describe this external state as a "kin-state" with a strong interest in policies toward their ethnic kin living as minorities in other states (Venice Commission 2001, Caspersen 2008, Waterbury 2010, Udrea 2014). ${ }^{6}$ Within the region, Hungary serves as a kin-state for Hungarians living in Romania, Slovakia, Serbia, and Croatia - as well as in Ukraine and Austria. Another frequent kin-state example used is that of Russia and the ethnic Russians living in Estonia and Latvia, as ethnic politics in those countries are inevitably linked to Russia. In addition, Turkey remains very interested in the fate of Turks in Bulgaria. Most kin-states in Eastern Europe have passed legislation that grants some legal status to their ethnic kin, and Hungary formally established dual citizenship in 2010.

In addition to kin-states, another external focus point with regard to minority politics in the region has been the European Union (EU). There has been a debate regarding the degree to which minority policies in the region have been affected by EU institutional conditionality (Vachudova 2001) or by Europeanisation, a process of socialisation to EU norms (Schmmelfennig and Sedelmeier 2005). With regard to policies on ethnic minorities, there is some debate on the degree to which the EU was in fact able to influence minority policy. There is some evidence that political elites were most likely to align with EU policies when they suited their own domestic goals (Csergo 2007). The next section focuses on these domestic political dynamics.

\section{B. Ethnic Minorities in Democratic Politics}

One of the early features of the post-1989 democracies in Eastern Europe was the emergence of ethnic parties, or parties defined according to an ethnic principle (Horowitz 1985). As many ethnic minorities had their own cultural and socialist organisations in the previous regimes, these institutions provided a base structure from which parties could arise. In addition, most of the East European states adopted proportional electoral systems during the 1990s. ${ }^{7}$ In such systems, voters cast their votes for parties, and the parliamentary share reflects the proportion of the vote given to each. Proportional representation encourages smaller parties, unlike the majoritarian electoral systems in the US and the UK. Ethnic parties have become a standard feature of the political landscape in many states, particularly for ethnic minorities. These ethnic parties tend to focus on identity-related issues, such as policies on language use and education, symbols, and increased governance powers for minorities (Horowitz 1985, Stroschein 2001, 2012).

Ethnic parties exhibit some traits that differ from parties as generally understood. Several minority groups throughout the region have well-organized ethnic parties, particularly within the Hungarians in Romania and Serbia, and previously among Hungarians in Slovakia. Albanians in Serbia and Macedonia also have quite institutionalised parties. Turks in Bulgaria have a party that is officially a multi-ethnic party, but which de facto is a party for their group.

\footnotetext{
${ }^{6}$ The Venice Commission document emerged to respond to a Hungarian state law passed in 2001 (The Status Law) that allocated benefits to ethnic Hungarians living in neighbouring states. I am grateful to Steve Saideman and Andreea Udrea for pointing me to some of this literature.

${ }^{7}$ There has been some institutional change, and Romania adopted a more majoritarian system for the 2008 elections.
} 
Systems with strong ethnic parties may feature "census" voting, in which the proportional voting percentages reflect the census data for particular ethnic groups (Horowitz 1985: 326). The fact that ethnic parties can only mobilise support within one ethnic group means that they do not tend to focus on broad appeals or issue-areas, but rather tend to have a focus on policies that affect the identity of their group. As outlined by Horowitz (1985), this internal focus tends to produce "outbidding" in ethnic parties. In the mechanism of outbidding, would-be party elites each attempt to be more "ethnic" than the others in an effort to gain support from within the limits of the ethnic population. For this reason, and informed by his work on Asia and Africa, Horowitz viewed ethnic parties as potentially dangerous political units that should be discouraged because they produce polarisation.

There are particular institutional rules that can affect the strength and behaviour of ethnic parties. In proportional representation systems, it is common to establish a percentage threshold of electoral support that parties must achieve in order to be included in parliaments. Thresholds are intended to exclude very small parties and to reduce the number of parties in such systems. They can also be designed to affect the ability of ethnic minority parties to obtain parliamentary representation. For example, Slovakia's electoral threshold was 5 percent in the 2012 elections, which led to the exclusion of some ethnic parties that had been longstanding political actors: the Hungarian Coalition Party and the Slovak National Party, a Slovak ethnic party. One ethnic group that has been less successful in mobilising throughout the region are the Roma. While there are some successful Roma elites across different countries, Roma populations tend to be fragmented in most of the countries in a way that is not conducive to strong ethnic party positioning (Vermeersch 2009; see also Vermeersch in this volume).

In addition to the electoral system and officeholder aspects, ethnic minority political dynamics also relates to levels of decentralisation within states in the region. Ethnic minorities may have some concentrations in enclaves, where they are the local ethnic majority. Some countries feature large and politically mobilised enclaves, such as the Hungarians in the Secuime region of Romania or Hungarians in the Žitný Ostrov region of south Slovakia, as well as Albanians in northwestern Macedonia. Claims for increased governance powers in enclaves often emerge, because key actors in such regions would often prefer more self-government over their own affairs - particularly in relation to identity-related policies on language and education. Ethnic majorities are often reluctant to agree to decentralisation or to grant autonomy, due to fears of loss of political control for the central state as well as the potential for autonomous units to become platforms for secession.

There has been an ongoing debate in the literature regarding whether decentralisation (including autonomy) might appease ethnic minorities, or whether it might encourage secession (Rothchild and Hartzell 1999, Mozaffar and Scarritt 1999, Cornell 2002). Academic consensus on this question remains elusive. Much of the current literature on decentralisation for ethnic minorities has now turned to focus on more specific conditions in each place, such as local demography (Hale 2004) or the role of parties (Brancati 2006). It has also been observed that the process of contesting potential decentralisation and autonomy may in fact lead to conflict, as ethnic minorities and majorities will tend to disagree on this issue (Sasse 2002).

Much literature on the design of democratic institutions has included a consideration of how to best address the question of ethnic minorities in democracy (Lijphart 1977, Horowitz 1985, Sisk 1999, and Reilly 2001 are some examples). Different approaches to electoral systems and to the degree of decentralisation or autonomy can be grouped according to two categories: 1) segmented or consociational; and B) integrative (Sisk 1999: 34-45). A segmented or consociational approach reflects Lijphart's (1977) understanding of consociationalism, in which ethnic groups in society remain separated to ensure representation. The main work of politics in a consociational structure is 
conducted by elites, who are envisioned to negotiate and cooperate with each other (Lijphart 1977). This echoes the logic of Fearon and Laitin's elite-led model outlined in Section III.A above, as well as the ideas of the conflict hypothesis. Groups are separate to ensure that their voices are heard, but there is also a latent assumption that it is unproductive for them to fully engage with each other the business of politics across groups is thus left to elites.

In contrast, the integrative approach envisions that groups should mix in politics. Thus, separate structures for different groups, including perhaps ethnic parties and potential autonomies, should be avoided. Rather, electoral systems should encourage political actors to make appeals across groups for votes, reducing the salience of ethnicity in the process, as do majoritarian and alternative vote ranked systems (Reilly 2001). This resonates with the contact hypothesis here - the notion that more mixing is healthy for a diverse society to stay together. The institutional approach favoured often depends on one's diagnosis of the problem: whether one thinks that more contact or less contact is the cause of potential ethnic conflicts and political stalemates.

\section{Questioning Principal Contributions on Ethnic Minorities and Democracy}

The biggest problem lurking in the contributions on ethnic minorities is that they reify minority groups as unified entities. Much work carries the assumption that ethnic groups are stable and unified entities, and this assumption simplifies the execution of statistical work that codes groups in this way in databases that assess the state of ethnicity across the globe. However, any time spent on the ground in Eastern Europe reveals that individuals within the same ethnic group will display vastly different political opinions and goals.

One of the most exciting recent developments in the study of ethnic minorities in fact relates to the way in which individuals within the same nominal ethnic group might exhibit quite different political stances, including toward ethnic policies. For example, the political claims of ethnic minorities that are concentrated in enclaves may differ greatly from the interests of other members of the ethnic minority who live dispersed outside of the enclave (Birnir 2006). Thus, claims for political autonomy for an ethnic enclave may be opposed by the titular majority, but also may not find favour from dispersed members of the same ethnic group who will fall outside of its proposed boundaries. In addition, interviews show that although individuals of the same group may have access to kin-state benefits, their individual propensities will produce varying degrees of engagement with those benefits (Brubaker et al 2006, Knott 2015). People may share the same ethnic name, but we may simply assume that means they engage in the same type of politics.

\section{Ethnic Minorities and the Future}

If ethnic minorities do not act as cohesive units, one might rightly ask why we should still study them. The answer lies in relation to the outline of historical developments at the beginning of this chapter. Ethnic minorities have especially salient identities in an environment of democratic political competition and ethnic parties. Ethnicity is politically salient in the contemporary context in a way that it could not be under socialism or under autocratic empires. This salience has been intertwined with episodes of violence in the 1990s that have consolidated identities in the region. Although Bosnia and Herzegovina and Croatia were the most extreme cases of inter-group violence, 
an ethnic riot also took place in Romania, and there are ongoing stories of skirmishes between ethnic groups. ${ }^{8}$

Recent political events also indicate that ethnicity remains a salient political mobilizer. Nearly all of the states in the region have passed kin-state legislation in which ethnic minorities in other states can access benefits from their "homeland" or kin-states. Dual citizenship, including voting rights, has also been introduced by Hungary in 2010, and Romania allows Moldovan citizens to become Romanian citizens and vote in elections (Knott 2015). Those individuals that benefit from these policies do not need to have ever lived in the kin-state, thus many of these benefits are applied in a cross-border manner that violates what some understand to be principles of state sovereignty established in 1648 (Deets and Stroschein 2005). However, a normative argument can also be made for the duties of states toward their ethnic kin (Udrea 2014).

In what may be an even more serious set of developments, the recent movement of refugees and migrants through Eastern Europe led to some strident reactions by political elites. In many instances, leaders are using a rhetoric of ethnic identity to justify blocking them on their journeys westward. Other types of attempts are also made to deny them entry or support. It may be the case that domestic ethnic minorities and majorities have normalized their interactions into democratic channels. But national identity remains potentially salient when faced with persons from an unfamiliar culture such as Syria, or an unfamiliar religion such as Islam. Some of the aggressive anti-other rhetoric of the 1990s has begun to re-emerge in light of these population flows. In Hungary, claims have been made that some ethnic minority Roma have aligned with Islamist groups among the refugees. Will more such links be made in other states, as hysteria is a powerful political force? More will certainly remain to be explained, using some of the literature insights outlined in this chapter.

\section{Conclusion}

In this chapter, I have summarized some of the primary discussions on the concept of ethnic minorities in Eastern Europe. The historical discussion indicates that ethnicity first became politically salient in the region during the 1800s. Within the context of democracy and ethnic parties, ethnicity has become a particularly salient political force. It is important to understand ethnic mobilization and ethnic group goals, as well as the notion of whether increased group contact leads to tolerance or to conflict. I have also considered literature on the dynamics of ethnic minority parties and elections, as well as political debates on ethnic minorities and decentralization and autonomy. While the chapter has emphasized general theories on ethnic minorities, I have concluded with some questions about the goal of general theories, and made a plea for some added nuance and specificity for the methods we use to examine these questions. In addition, the literature may need to expand to include a consideration of immigrants, migrants, and refugees in a more cohesive manner. Recent events indicate that group differences will remain a salient force in the region, in meaningful and perhaps disturbing ways.

\section{References}

Allport, G. (1954) The Nature of Prejudice. New York: Basic Books, 1979 edition.

\footnotetext{
8 Participant observation in the region by the author has involved stories of Hungarians being thrown off of trains in Slovakia, bar fights between Hungarians and Romanians in Romania, and continued suspicion of other groups in Bosnia and Herzegovina.
} 
Anderson, B. (1991) [1983] Imagined Communities: Reflections on the Origin and Spread of Nationalism. New York: Verso.

Banac, I. (1984) The National Question in Yugoslavia: Origins, History, Politics. Ithaca: Cornell University Press.

Birnir, J. (2006) Ethnicity and Electoral Politics. New York: Cambridge University Press.

Brancati, D. (2006) "Decentralization: Fueling the Fire or Dampening the Flames of Ethnic Conflict and Secessionism?" International Organization 60 (3): 651-686.

Brubaker, R. (1996) "National Minorities, Nationalizing States, and External National Homelands in the New Europe," Chapter 3 of Nationalism Reframed: Nationhood and the National Question in Europe. New York: Cambridge University Press: 55-76.

Brubaker, R., M. Feischmidt, J. Fox, and L. Grancea (2006) Nationalist Politics and Everyday Ethnicity in a Transylvanian Town. Princeton, NJ: Princeton University Press.

Carnegie Endowment for International Peace (1993) The Other Balkan Wars: A 1913 Carnegie Endowment Inquiry in Retrospect with a New Introduction and Reflections on the Present Conflict by George F. Kennan. Washington, DC: The Carnegie Endowment for International Peace.

Caspersen, N. (2008) "Between Puppets and Independent Actors: Kin-State Involvement in the Conflicts in Bosnia, Croatia and Nagorno Karabakh," Ethnopolitics 7 (4): 357-372.

Chandra, K. (2006) "What is Ethnic Identity and Does it Matter?" Annual Review of Political Science 9: 397-424.

Connor, Walker (1994) "A Nation is a Nation, Is a State, Is and Ethnic Group, Is a...". In Ethnonationalism: The Quest for Understanding. Princeton, NJ: Princeton University Press.

Cornell, S. (2002) "Autonomy as a Source of Conflict: Caucasian Conflicts in Theoretical Perspective." World Politics 54(2): 245-276.

Csergo, Zs. (2007) Talk of the Nation: Language and Conflict in Romania and Slovakia. Ithaca, NY: Cornell University Press.

Deets, S., and S. Stroschein (2005) "Dilemmas of Autonomy and Liberal Pluralism: Examples Involving Hungarians in Central Europe." Nations and Nationalism 11 (2): 285-305.

Fearon, J. (1994) "Ethnic War as a Commitment Problem," paper presented at the American Political Science Association, New York, August 30-September 2, 1994. 1995 version online, available at: https://web.stanford.edu/group/fearon-research/cgi-bin/wordpress/wpcontent/uploads/2013/10/Ethnic-War-as-a-Commitment-Problem.pdf

Fearon, J., and D. Laitin (1996) "Explaining Interethnic Cooperation," American Political Science Reivew 90 (4): 715-35.

Gati, C. (1990) The Bloc that Failed: Soviet-East European Relations in Transition. Bloomington, IN: Indiana University Press.

Gellner, E. (1983) Nations and Nationalism. Ithaca, NY: Cornell University Press.

Glassheim, E. (2005) Noble Nationalists: The Transformation of the Bohemian Aristocracy. Cambridge, MA: Harvard University Press. 
Glenny, M. (1993) [1992] The Fall of Yugoslavia: The Third Balkan War. New York: Penguin Books. Hobsbawm, E. J. (1992) Nations and Nationalism Since 1780: Programme, Myth, Reality. London: Cambridge University Press.

Horowitz, D. (1985) Ethnic Groups in Conflict. Berkeley: The University of California Press.

Hupchick, D., and H. Cox. (2001a) The Palgrave Concise Historical Atlas of Eastern Europe. New York: Palgrave.

Hupchick, D., and H. Cox (2001b) The Palgrave Concise Historical Atlas of the Balkans. New York: Palgrave.

Jelavich, B. (1983) History of the Balkans: Eighteenth and Nineteenth Centuries, Volume I. Cambridge: Cambridge University Press. 1995 edition used.

Kann, R., and Z. David (1984) The Peoples of the Eastern Habsburg Lands, 1526-1918. Seattle and London: University of Washington Press.

Kaplan, R. (1994) [1993] Balkan Ghosts: A Journey through History. New York: St. Martin's Press. 1994 edition used.

Knott, E. (2015) Kin-States and Kin Majorities from the bottom-up: Testing a Model of Nested Integration in Crimea and Moldova. PhD thesis, London School of Economics and Political Science.

Lendvai, P. (2003) The Hungarians: 1000 Years of Victory in Defeat. London: Hurst \& Co.

Lijphart, A. (1977) Democracy in Plural Societies: A Comparative Explanation. New Haven: Yale University Press.

Magocsi, P. R. (1995) [1993] Historical Atlas of East Central Europe. Seattle and London: University of Washington Press. 1995 edition used.

Massey, G., R. Hodson, and D. Sekulić (1999) “Ethnic Enclaves and Intolerance: The Case of Yugoslavia," Social Forces 78(2): 669-693.

Mozaffar, S., and J. Scarritt (1999) "Why Territorial Autonomy is Not a Viable Option for Managing Ethnic Conflict in African Plural Societies." Nationalism and Ethnic Politics 5 (3-4): 230-253.

Muiznieks, N. (1997) "Latvia: Restoring a State, Rebuilding a Nation." In lan Bremmer and Ray Taras, eds., New States New Politics: Building the Post-Soviet Nations. New York: Cambridge University Press, pp. 376-403.

Raun, T. (1997) "Estonia: Independence Redefined." In lan Bremmer and Ray Taras, eds., New States New Politics: Building the Post-Soviet Nations. New York: Cambridge, pp. 405-433.

Reilly, B. (2001) Democracy in Divided Societies: Electoral Engineering for Conflict Management. New York: Cambridge University Press.

Rothchild, D., and C. Hartzell (1999) "Security in Deeply Divided Societies: The Role of Territorial Autonomy." Nationalism and Ethnic Politics 5 (3-4): 254-271.

Rothschild, J. (1992) [1974] East Central Europe between the Two World Wars. Seattle and London: University of Washington Press. 1992 edition used. 
Rothschild, J. (1989) Return to Diversity: A Political History of East Central Europe Since World War II. Oxford: Oxford University Press.

Sasse, G. (2002) "Conflict-Prevention in a Transition State: The Crimean Issue in Post-Soviet Ukraine." Nationalism and Ethnic Politics 8 (2): 1-26.

Schimmelfennig, F., and U. Sedelmeier, eds. (2005) The Europeanization of Central and Eastern Europe. Ithaca, NY: Cornell University Press.

Sebők, L. (1998) “Nationality Map of East Central and Southeast Europe.” Budapest: Teleki László Foundation, published by Südost Institut Munich.

Senn, A. (1997) "Lithuania: Rights and Responsibilities of Independence." In lan Bremmer and Ray Taras, eds., New States New Politics: Building the Post-Soviet Nations. New York: Cambridge, pp. 353-375.

Sisk, T. (1999) Power Sharing and International Mediation in Ethnic Conflicts. Washington, DC: United States Institute of Peace.

Smith, A. (1986) The Ethnic Origins of Nations. Cambridge: Blackwell Publishers.

Snyder, J. (2000) From Voting to Violence: Democratization and Nationalist Conflict. New York: W.W. Norton \& Co.

Stokes, G. (1993) The Walls Came Tumbling Down: The Collapse of Communism in Eastern Europe. London: Oxford University Press.

Stroschein, S. (2001) "Measuring Ethnic Party Success in Romania, Slovakia, and Ukraine." Problems of Post-Communism 48 (4): 59-69.

Stroschein, S. (2011) "Demography in Ethnic Party Fragmentation: Hungarian Local Voting in Romania." Party Politics 17 (2): 189-204.

Stroschein, S. (2012) Ethnic Struggle, Coexistence, and Democratization in Eastern Europe. New York: Cambridge University Press.

Szakály, F. (1990) “The Early Ottoman Period, Including Royal Hungary, 1526-1606." In P. Sugar, P. Hanák, and T. Frank, eds., A History of Hungary. Bloomington: Indiana University Press, pp. 83-99.

Udrea, A. (2014) “A Kin-State's Responsibility: Cultural Identity, Recognition, and the Hungarian Status Law." Ethnicities 14 (2): 324-346.

Vachudova, M. (2001) Europe Undivided: Democracy, Leverage, and Integration after Communism. London: Oxford University Press.

Venice Commission. (2001) Preferential Treatment of National Minorities by their Kin-State, Draft Report. Strausbourg: Council of Europe, 16 October. CDL (2001) 097-e.

Vermeersch, P. (2009) "In Search of a Movement: The Opportunities and Limits of Romani Political Solidarity”. Südosteuropa Mitteilungen 49(2): 88-94.

Waterbury, M. (2010) Between State and Nation: Diaspora Politics and Kin-State Nationalism in Hungary. New York: Palgrave.

Woodward, S. (1995) Balkan Tragedy: Chaos and Destruction after the Cold War. Washington, DC: The Brookings Institution. 
